\title{
Circulating calcification inhibitors are associated with arterial damage in pediatric patients with primary hypertension
}

\author{
Piotr Skrzypczyk ${ }^{1}$ (1) - Anna Stelmaszczyk-Emmel ${ }^{2}$ (D) - Michał Szyszka ${ }^{1} \cdot$ Anna Ofiara ${ }^{1}$ • \\ Małgorzata Pańczyk-Tomaszewska ${ }^{1}$ (D)
}

Received: 5 July 2020 / Revised: 26 December 2020 / Accepted: 19 January 2021 / Published online: 18 February 2021

(C) The Author(s) 2021

\begin{abstract}
Background Circulating calcification inhibitors: fetuin A (FA) and osteoprotegerin (OPG) together with soluble ligand of receptor activator of nuclear factor kappa-B (sRANKL) have been linked to vascular calcifications and arterial damage. This study aimed to evaluate relationships between FA, OPG, SRANKL, and arterial damage in children with primary hypertension (PH).

Methods In this cross-sectional single-center study, calcification inhibitors (FA, OPG, sRANKL) levels were measured in blood samples of 60 children with PH (median age 15.8, IQR: [14.5-16.8] years) and 20 age-matched healthy volunteers. In each participant, peripheral and central blood pressure evaluation (BP) and ambulatory BP monitoring (ABPM) were performed. Arterial damage was measured using common carotid artery intima media thickness (cIMT), pulse wave velocity (PWV), augmentation index (AIx75HR), and local arterial stiffness (ECHO-tracking-ET) analysis.

Results Children with PH had significantly higher peripheral and central BP, BP in ABPM, thicker cIMT, higher PWV, and AIx75HR. FA was significantly lower in patients with PH compared to healthy peers without differences in OPG, sRANKL, and OPG/sRANKL and OPG/FA ratios. In children with PH, FA level correlated negatively with cIMT Z-score and ET AIx; sRANKL level correlated negatively with ABPM systolic blood pressure (SBP), SBP load, diastolic BP load, and AIx75HR; OPG/sRANKL ratio correlated positively with SBP load, while OPG/FA ratio correlated positively with ET AIx. In multivariate analysis, FA was a significant determinant of cIMT (mm) and cIMT Z-score.

Conclusions This study reveals that in children with primary hypertension, arterial damage is related to lower fetuin A concentrations.
\end{abstract}

Keywords Primary hypertension $\cdot$ Children $\cdot$ Arterial damage $\cdot$ Calcification inhibitors $\cdot$ Fetuin A

\section{Introduction}

Primary hypertension $(\mathrm{PH})$ is a complex systemic disorder involving in its pathogenesis genetic factors, environmental factors (e.g., sedentary lifestyle, high-sodium diet), inappropriate body composition and fatty tissue distribution,

Piotr Skrzypczyk

pskrzypczyk@wum.edu.pl

1 Department of Pediatrics and Nephrology, Medical University of Warsaw, ul. Żwirki i Wigury 63A, 02-091 Warsaw, Poland

2 Department of Laboratory Diagnostics and Clinical Immunology of Developmental Age, Medical University of Warsaw, ul. Żwirki i Wigury 63A, 02-091 Warsaw, Poland dysregulation of sympathetic, immune, and reninangiotensin-aldosterone systems, endothelial dysfunction, gut microbiota dysbiosis, as well as premature (early) vascular aging [1].

Increased arterial stiffness and abnormal common carotid artery intima-media thickness (cIMT) have been recognized as independent risk factors for cardiovascular morbidity and mortality in adult populations [2, 3]. However, increased arterial stiffness and cIMT abnormalities are not uncommon in pediatric patients with $\mathrm{PH}$ [4]. Recent experimental studies indicate that arterial lesions are associated with endothelial dysfunction, subclinical inflammation, oxidative stress, altered smooth muscle cell number, structure and function, and vascular calcification processes [5]. Vascular calcification is an active, cell-regulated process, which may substantially worsen arterial damage, with numerous molecules involved. 
Fetuin-A (FA) ( $\alpha 2$-Heremans-Schmid glycoprotein) is a soluble glycoprotein produced exclusively by hepatocytes and released into the circulation in high concentrations. It is involved in several functions, such as endocytosis, brain development, insulin resistance, and formation of bone tissue, and shows negative correlations with systemic and local inflammation. FA, considered the most potent systemic inhibitor of calcification, forms a soluble complex comprised of 8 FA molecules, 790 calcium atoms, and 58 phosphate molecules (calciprotein), protecting against formation of extraosseous calcium deposits $[6,7]$.

Osteoprotegerin (OPG) is a soluble glycoprotein, found as either a $60 \mathrm{kDa}$ monomer or $120 \mathrm{kDa}$ dimer, produced by osteoblasts, epithelial cells, vascular endothelial cells, as well as B cells and dendritic cells. In bone tissue, OPG acts as a decoy receptor for soluble ligand of the receptor activator of nuclear factor kappa-B (sRANKL). Once released by osteoblasts, sRANKL binds to RANK receptor on the surface of osteoclast progenitor cells, thus activating the nuclear factor kappa B (NF-KB) and triggering osteoclast precursor cell differentiation into mature osteoclasts, which in turn increases bone resorption. Recently, OPG was found to exert numerous systemic, extraosseous actions including inhibition of soft tissue and vascular calcifications $[8,9]$.

Studies in vitro and in animal models suggest that both OPG and FA inhibit vascular calcification $[10,11]$. Numerous adult data on the significance of these molecules as biomarkers of subclinical arterial damage in patients with chronic kidney disease (CKD) [12], coronary artery disease [13], and PH [14, 15] give inconsistent results. There are only a few pediatric studies analyzing relationships between cIMT or arterial stiffness and the aforementioned biomarkers [16-20].

To the best of our knowledge, there is no data in the literature analyzing dependence between target-organ damage, FA, OPG, and sRANKL in pediatric patients with PH. Thus, the aim of this study was to characterize the relationships between these circulating biomarkers and subclinical arterial damage, elevated blood pressure, and clinical parameters in children and adolescents with $\mathrm{PH}$.

\section{Methods}

\section{Patients}

This cross-sectional analysis included 60 pediatric patients with PH aged from 5.6 to 17.9 years hospitalized in one pediatric nephrology department between January and December 2018. Arterial hypertension was diagnosed according to current European guidelines [21]. The following exclusion criteria were used: secondary forms of hypertension, known kidney, heart, vascular or calcium-phosphorus pathology, as well as acute infections (temporary exclusion for 4 weeks). Twenty age- and sex-matched healthy subjects were included in the control group. The flow diagram of the participants is displayed in Fig. 1. The sample size of the study group, assessed on the basis of available literature, should be 60 (statistical power $0.80, \mathrm{P}=0.05$ ).

\section{Calcification inhibitors and calcium-phosphorus metabolism}

Venous blood was collected after 12-h fasting, centrifuged to obtain serum, and stored at $-80^{\circ} \mathrm{C}$. Concentrations of vascular calcification inhibitors were measured using enzyme-linked immunosorbent assays (ELISA) (Fetuin-A [AHSG] Human ELISA kit Ca. No. RD191037100 $[\mu \mathrm{g} / \mathrm{mL}]$, Osteoprotegerin Human ELISA kit Cat. No. RD194003200 [pmol/L], sRANKL Human ELISA kit Cat. No. RD193004200R [pmol/L], Biovendor, Brno, Czech Republic). In addition, we assessed basic parameters of calcium-phosphorus metabolism: 25(OH)D $[\mathrm{ng} / \mathrm{mL}]$, calcium $[\mathrm{mg} / \mathrm{dL}]$, inorganic phosphorus $[\mathrm{mg} / \mathrm{dL}]$, alkaline phosphatase [IU/L], and intact parathormone (PTH) $[\mathrm{pg} / \mathrm{mL}]$. Vitamin D concentrations were defined according to Polish recommendations [22]. Normal concentrations of calcium $(8.8-10.7 \mathrm{mg} / \mathrm{dL})$, phosphorus $(2.8-5.6 \mathrm{mg} /$ $\mathrm{dL}$ ), alkaline phosphatase (45-515 IU/L), and parathormone $(12-95 \mathrm{pg} / \mathrm{mL}$ ) were taken from normative values according to the manufacturers' recommendations. Vitamin D and parathormone were assessed by chemiluminescence (Alinity ci, Abbott Laboratories, Lake Bluff, IL, USA, and IMMULITE 2000XPi, Siemens Healthineers, Erlangen, Germany, respectively), all other parameters by dry chemistry (VITROS 5600, Ortho Clinical Diagnostics, Raritan, NJ, USA). Complete blood count (CBC) was performed using Coulter LH 780 hematologic analyzer (Sysmex XN1000, Sysmex Corporation, Kobe, Japan) and the following CBC-derived inflammatory indicators were evaluated: numbers of neutrophils (NEU) $[1000 / \mu \mathrm{L}]$, lymphocytes $(\mathrm{LYM} ; 1000 / \mu \mathrm{L})$, platelets (PLT; $1000 / \mu \mathrm{L}$ ), mean platelet volume (MPV) [fL], and neutrophilto-lymphocyte and platelet-to-lymphocyte ratios (NLR and PLR, respectively).

\section{Blood pressure and subclinical arterial damage}

The detailed methodology of blood pressure and arterial damage assessment was described previously [23, 24]. Peripheral office blood pressure (BP) was measured oscillometrically with Welch Allyn VSM Patient Monitor 300 (Welch Allyn Inc., Skaneateles Falls, NY, USA) [mmHg] Z-scores [25]. Twenty-four-hour ABPM was performed using the SUNTECH OSCAR 2 device (SunTech Medical, Inc., Morrisville, NC, USA). We analyzed the following ABPM-derived parameters during $24 \mathrm{~h}$ : systolic, diastolic, and mean arterial pressure (SBP $24 \mathrm{~h}$, DBP $24 \mathrm{~h}$, MAP $24 \mathrm{~h}$, respectively) [mmHg], MAP $24 \mathrm{~h}$ Z-score, pulse pressure 


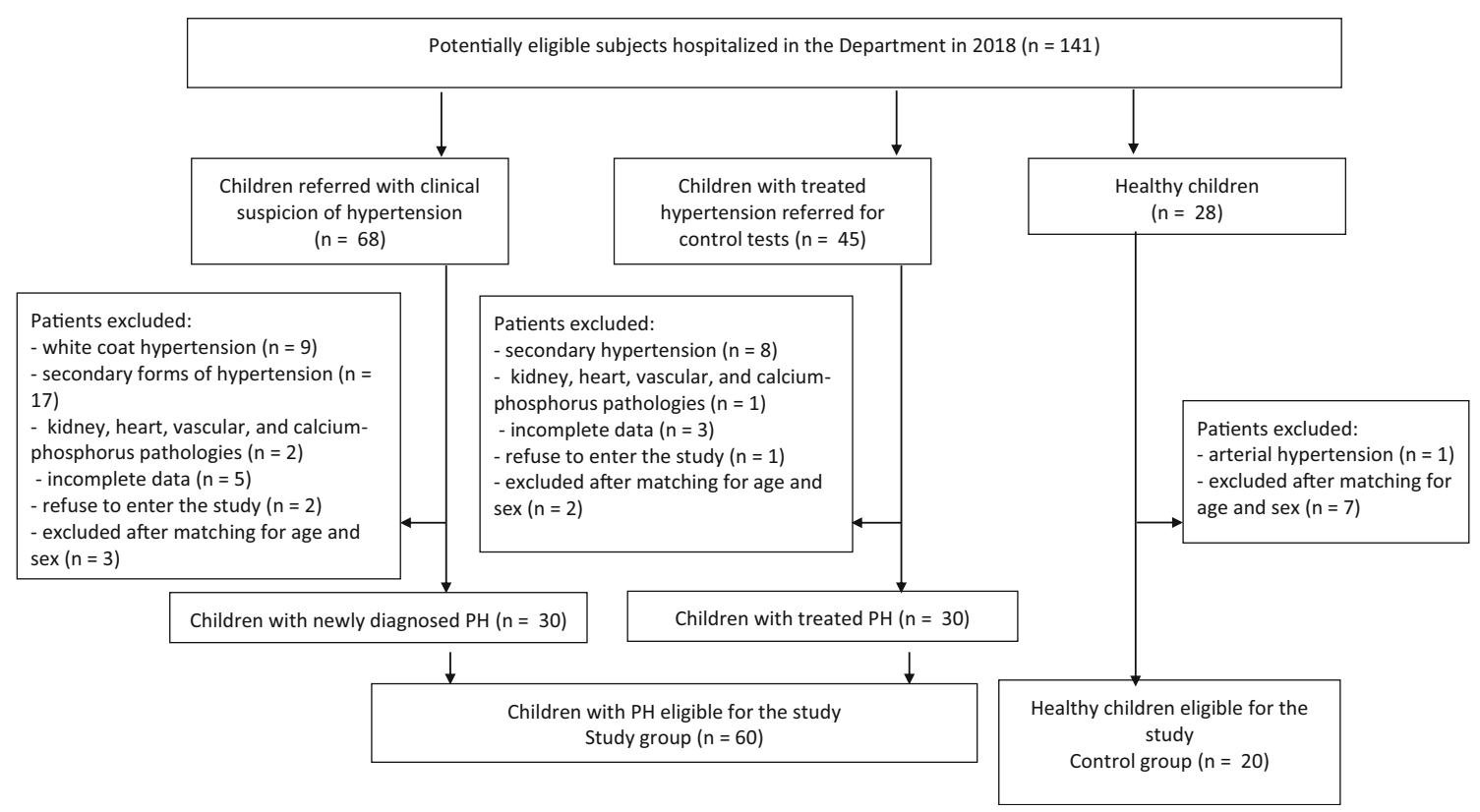

Fig. 1 Flow diagram of the studied population ( $\mathrm{PH}$ - primary hypertension)

[mmHg], heart rate [beats per minute], SBP and DBP load [\%], and nocturnal blood pressure dip [\%] [26]. Central (aortic) blood pressure (AoBP) $[\mathrm{mmHg}]$, augmentation index normalized to heart rate of 75 beats per minute (AIx75HR) [\%], subendocardial viability ratio (SEVR) [\%], and aortic pulse wave velocity (PWV) $[\mathrm{m} / \mathrm{s}]$ were evaluated with the Sphygmocor device (AtCor Medical Pty Ltd., Sydney, Australia) using applanation tonometry, and common carotid intima media thickness (cIMT) $[\mathrm{mm}]$ was measured using the Aloka Prosound Alpha 6 (Hitachi Aloka Medical, Mitaka, Japan) equipped with 13-MHz linear transducer. In addition, the following elasticity parameters of right common carotid artery (local arterial stiffness) by ECHOtracking (ET) Aloka Prosound Alpha 6 preset were analyzed: beta (stiffness index), Ep (pressure strain elasticity modulus) $[\mathrm{kPa}], \mathrm{AC}$ (arterial compliance) $\left[\mathrm{mm}^{2} / \mathrm{kPa}\right]$, AIx (augmentation index) [\%], PWVbeta (pulse wave velocity beta) $[\mathrm{m} / \mathrm{s}], D_{-} \max$ [mm], $D \_$min [mm] (maximal and minimal diameter of the artery), DATmax (acceleration time to artery maximal diameter) [ms]. PWV, cIMT are expressed as absolute values and Z-scores using pediatric normative data $[27,28]$.

\section{Clinical and biochemical parameters}

In all children, basic clinical and anthropometrical data were assessed (age [years], sex, duration of PH [months], height $[\mathrm{cm}]$, weight $[\mathrm{kg}]$, and body mass index (BMI) $\left.\left[\mathrm{kg} / \mathrm{m}^{2}\right]\right)$; all anthropometrical parameters are presented as Z-scores [29]. Overweight and obesity were defined in accordance with World Health Organization as BMI Z-score values $>1$ and $>2$, respectively.

In addition, the following biochemical parameters were evaluated in all study subjects: serum creatinine $[\mathrm{mg} / \mathrm{dL}]$, uric acid [mg/dL], total, low-density lipoprotein (LDL) and highdensity lipoprotein (HDL) cholesterol [mg/dL], and triglycerides $[\mathrm{mg} / \mathrm{dL}]$; biochemical parameters were evaluated by dry chemistry (VITROS 5600, Ortho Clinical Diagnostics, USA). Glomerular filtration rate (GFR) was calculated according to the Schwartz formula [30].

\section{Statistical analysis}

Statistical analysis was performed using Dell Statistica 13.0 software (TIBCO Software Inc. Palo Alto, CA, USA). Normality of data was analyzed using the Shapiro-Wilk test. The results were expressed as mean $\pm \mathrm{SD}$ (normal distribution) or median and interquartile range (IQR) (non-normal distribution). Quantitative variables were compared for homogeneity using the Student $t$ test (normal distribution) or the Mann-Whitney U test (non-normal distribution). The numbers of patients in subgroups were compared using the chi-square test and Fisher exact test. The relationship between quantitative variables were analyzed using Pearson correlation or Spearman's rank correlation, when appropriate. Multivariate analysis was performed using forward step-wise regression analysis. Parameters that correlated with markers of arterial damage with $p<0.100$ in the univariate analysis were included in the final model. Parameters that correlated with each other with $r>0.650$ were excluded from the regression models so as to avoid collinearity. To detect the outliers and measure the impact on the regression equation, Cook's distance and standardized residual values were used. The variables that caused outliers were removed from regression models. A $p$ value of $<0.05$ was considered statistically significant. 
Table 1 Clinical and biochemical characteristics of the studied population.

\begin{tabular}{llll}
\hline Analyzed parameter & $\begin{array}{l}\text { Children with arterial hypertension } \\
(n=60)\end{array}$ & $\begin{array}{l}\text { Healthy children }(n= \\
20)\end{array}$ & $P$ \\
\hline Sex (boys/girls) (n) & $37 / 23$ & $11 / 9$ & $\mathrm{P}=0.609^{\mathrm{a}}$ \\
Age [years] & $15.8(14.5-16.8)$ & $14.8(13.0-16.4)$ & $\mathrm{P}=0.207^{\mathrm{b}}$ \\
Height [cm] & $170.5(161.8-178.8)$ & $165.0(151.5-171.5)$ & $\mathrm{P}=0.088^{\mathrm{b}}$ \\
Height Z-score & $0.53 \pm 1.00(-0.29-1.16)$ & $0.69 \pm 1.23(0.13-1.22)$ & $\mathrm{P}=0.555^{\mathrm{c}}$ \\
Weight [kg] & $72.0(61.3-84.7)$ & $56.0(46.0-61.0)$ & $\mathrm{P}<0.001^{\mathrm{b}}$ \\
Weight Z-score & $1.20 \pm 0.81$ & $0.62 \pm 0.98$ & $\mathrm{P}=0.010^{\mathrm{c}}$ \\
BMI [kg/m ${ }^{2}$ ] & $24.7 \pm 4.5$ & $20.7 \pm 3.6$ & $\mathrm{P}=0.001^{\mathrm{c}}$ \\
BMI Z-score & $1.17(0.52-1.73)$ & $0.14(-0.43-1.12)$ & $\mathrm{P}=0.001^{\mathrm{b}}$ \\
GFR ac. to Schwartz & $93.9(87.0-109.2)$ & $101.8(95.4-121.9)$ & $\mathrm{P}=0.076^{\mathrm{b}}$ \\
$\quad$ [mL/min/1.73 m $\left.{ }^{2}\right]$ & $5.6 \pm 1.4$ & $4.6 \pm 1.1$ & $\mathrm{P}=0.003^{\mathrm{c}}$ \\
Uric acid [mg/dL] & $150(129-169)$ & $148(135-180)$ & $\mathrm{P}=0.899^{\mathrm{b}}$ \\
Total cholesterol [mg/dl] & $48(42-55)$ & $58.5(53-70)$ & $\mathrm{P}=0.001^{\mathrm{b}}$ \\
HDL-cholesterol [mg/dL] & $83.5(64.5-96.8)$ & $77.3(63.8-103.6)$ & $\mathrm{P}=0.701^{\mathrm{b}}$ \\
LDL-cholesterol [mg/dL] & $85.5(64-120)$ & $57.5(49.50-71.50)$ & $\mathrm{P}=0.001^{\mathrm{b}}$ \\
Triglycerides [mg/dL] & $10.6(9.9-11.2)$ & $11.0(10.2-11.4)$ & $P=0.077^{\mathrm{b}}$ \\
MPV [fL] & $1.49(1.18-2.06)$ & $1.20(0.89-1.53)$ & $\mathrm{P}=0.040^{\mathrm{b}}$ \\
NLR & $130.14 \pm 45.21$ & $118.94 \pm 29.28$ & $\mathrm{P}=0.303^{\mathrm{c}}$ \\
PLR & & &
\end{tabular}

$B M I$ body mass index, GFR glomerular filtration rate, $H D L$ high-density lipoprotein, $L D L$ low-density lipoprotein, $M P V$ mean platelet volume, $N L R$ neutrophil-to-lymphocyte ratio, $P L R$ platelet-to-lymphocyte ratio

${ }^{\text {a }}$ Fisher's exact test

${ }^{\mathrm{b}}$ Mann-Whitney $U$ test

${ }^{\mathrm{c}}$ Student $t$ test

\section{Results}

Clinical and biochemical characteristics of the studied children are shown in Table 1. PH patients did not differ from healthy children in terms of sex, age, and kidney function, as well as total and LDL cholesterol. Hypertensive children were characterized by higher BMI Z-score $(1.17(0.52-1.73)$ vs. 0.14 (-0.43-1.12), $P=0.001)$, uric acid (5.6 \pm 1.4 vs. $4.6 \pm$ $1.1[\mathrm{mg} / \mathrm{dL}], P=0.003)$, and triglycerides $(85.5(64-120) \mathrm{vs}$. $57.5(49.50-71.50)[\mathrm{mg} / \mathrm{dL}], P=0.003)$, and lower HDLcholesterol (48 (42-55) vs. $58.5(53-70)[\mathrm{mg} / \mathrm{dL}], P=$ 0.001 ) compared to the healthy ones. When we analyzed subclinical inflammation markers, we found that $\mathrm{PH}$ children had significantly higher NLR (1.49 (1.18-2.06) vs. 1.20 (0.891.53), $P=0.040$ ) without differences in MPV and PLR in comparison to the control group. Among PH patients, 25 $(41.7 \%)$ children were overweight, and $8(13.3 \%)$ were obese. Duration of hypertension was $19.9 \pm 25.7$ (median value: 12.0, IQR: [4.0-24.5]) [months]. In the study group, half of the patients had already been treated with antihypertensive medications. Amlodipine, prescribed in 18 patients, was the most commonly used medication. Other medications were angiotensin-converting enzyme inhibitors in 11 , betablockers in 4 , angiotensin receptor blockers in 2, alpha- blockers in 1 , and hydrochlorothiazide in 1 child. The vast majority of treated children received 1 antihypertensive drug, three children received 2 medications, and two children received 3 drugs. The remaining 30 children were newly diagnosed with $\mathrm{PH}$ and no treatment was administered yet.

Peripheral blood pressure, the results of ABPM, central blood pressure, arterial stiffness parameters, cIMT, and Etracking parameters are presented in Table 2. $\mathrm{PH}$ patients were characterized by significantly higher office peripheral and central blood pressures (SBP: $132.2 \pm 12.2$ vs. $117.0 \pm 9.9$ $[\mathrm{mmHg}], \mathrm{P}<0.001$, DBP: 77.5 (73-83) vs. 67.5 (62-70) [mmHg], P < 0.001, AoSBP: 108.3 (103-117) vs. 95.5 (89103) $[\mathrm{mmHg}]$, P < 0.001, AoDBP: 79.0 (74-85) vs. 69.0 (6371) [mmHg], P < 0.001, AoMAP: 94.3 (88-99) vs. 83.5 (7687) $[\mathrm{mmHg}], \mathrm{P}<0.001)$, ABPM blood pressure (24 h SBP: $128.4 \pm 7.9$ vs. $113.0 \pm 6.1[\mathrm{mmHg}], \mathrm{P}<0.001,24 \mathrm{~h} \mathrm{DBP}:$ $70.0 \pm 6.3$ vs. $63.2 \pm 3.9[\mathrm{mmHg}], P<0.001,24$ h MAP: 89.3 \pm 6.0 vs. $79.7 \pm 3.5[\mathrm{mmHg}], \mathrm{P}<0.001)$, PWV (5.0 (4.6-5.7) vs. $4.5(3.9-4.8)[\mathrm{m} / \mathrm{s}], P=0.007)$, cIMT $(0.46 \pm 0.07$ vs. 0.39 $\pm 0.03[\mathrm{~mm}], \mathrm{P}<0.001)$, and common carotid artery maximal and minimal diameters derived from ECHO-tracking (ET D max: $6.4 \pm 0.7$ vs. $5.9 \pm 0.7[\mathrm{~mm}], \mathrm{P}=0.010$, ET D min: $5.5 \pm$ 0.7 vs. $5.1 \pm 0.7[\mathrm{~mm}], \mathrm{P}=0.021$ ). At the moment of evaluation, elevated (i.e., equal or above $95^{\text {th }}$ percentile) office 
Table 2 Blood pressure and parameters of arterial damage in children with primary hypertension and in control group

\begin{tabular}{|c|c|c|c|}
\hline Analyzed parameter & Children with arterial hypertension $(n=60)$ & Healthy children $(n=20)$ & $\mathrm{P}$ \\
\hline $\mathrm{SBP}[\mathrm{mmHg}]$ & $132.2 \pm 12.2$ & $117.0 \pm 9.9$ & $P<0.001^{\mathrm{a}}$ \\
\hline SBP Z-score & $2.30 \pm 0.94$ & $0.65 \pm 0.86$ & $P<0.001^{\mathrm{a}}$ \\
\hline $\mathrm{DBP}[\mathrm{mmHg}]$ & $77.5(73-83)$ & $67.5(62-70)$ & $P<0.001^{\mathrm{b}}$ \\
\hline DBP Z-score & $1.51 \pm 0.91$ & $0.18 \pm 0.67$ & $P<0.001^{\mathrm{a}}$ \\
\hline AoSBP $[\mathrm{mmHg}]$ & $108.3(103-117)$ & $95.5(89-103)$ & $P<0.001^{\mathrm{b}}$ \\
\hline AoDBP $[\mathrm{mmHg}]$ & $79.0(74-85)$ & $69.0(63-71)$ & $P<0.001^{\mathrm{b}}$ \\
\hline AoMAP $[\mathrm{mmHg}]$ & $94.3(88-99)$ & $83.5(76-87)$ & $P<0.001^{\mathrm{b}}$ \\
\hline 24h SBP $[\mathrm{mmHg}]$ & $128.4 \pm 7.9$ & $113.0 \pm 6.1$ & $P<0.001^{\mathrm{a}}$ \\
\hline 24h DBP [mmHg] & $70.0 \pm 6.3$ & $63.2 \pm 3.9$ & $P<0.001^{\mathrm{a}}$ \\
\hline 24h MAP [mmHg] & $89.3 \pm 6.0$ & $79.7 \pm 3.5$ & $P<0.001^{\mathrm{a}}$ \\
\hline 24h MAP Z-score & $0.90(0.17-1.61)$ & $-0.54(-0.87-0.08)$ & $P<0.001^{\mathrm{b}}$ \\
\hline 24h SBPL [\%] & $37.5(22-55)$ & $6.9(4-16)$ & $P<0.001^{\mathrm{b}}$ \\
\hline 24h DBPL [\%] & $17.5(8-26)$ & $7.0(1-10)$ & $P<0.001^{\mathrm{b}}$ \\
\hline SBP DIP [\%] & $10.8 \pm 5.0$ & $10.3 \pm 4.0$ & $P=0.657^{\mathrm{a}}$ \\
\hline DBP DIP [\%] & $15.9 \pm 7.5$ & $15.7 \pm 5.5$ & $P=0.943^{\mathrm{a}}$ \\
\hline AIx75HR [\%] & $-6.3(-11.5-4.8)$ & $-3.0(-9.2-2.2)$ & $P=0.685^{\mathrm{b}}$ \\
\hline SEVR [\%] & $149.8(133-186)$ & $153.5(136-172)$ & $P=0.859^{\mathrm{b}}$ \\
\hline $\mathrm{PWV}[\mathrm{m} / \mathrm{s}]$ & $5.0(4.6-5.7)$ & $4.5(3.9-4.8)$ & $P=0.007^{\mathrm{b}}$ \\
\hline PWV Z-score & $-0.18 \pm 1.18$ & $-0.99 \pm 0.94$ & $P=0.007^{\mathrm{a}}$ \\
\hline cIMT $[\mathrm{mm}]$ & $0.46 \pm 0.07$ & $0.39 \pm 0.03$ & $P<0.001^{\mathrm{a}}$ \\
\hline cIMT Z-score & $1.44 \pm 1.40$ & $0.16 \pm 0.57$ & $P<0.001^{\mathrm{a}}$ \\
\hline ET beta & $3.5(2.7-4.3)$ & $3.6(3.2-4.6)$ & $P=0.487^{\mathrm{b}}$ \\
\hline ET Ep [kPa] & $46.5(35-59)$ & $42.0(35-53)$ & $P=0.512^{\mathrm{b}}$ \\
\hline $\mathrm{ET} \mathrm{AC}\left[\mathrm{mm}^{2} / \mathrm{kPa}\right]$ & $1.1(0.9-1.5)$ & $1.0(0.8-1.2)$ & $P=0.220^{\mathrm{b}}$ \\
\hline ET AIx [\%] & $-2.2(-8.7-1.3)$ & $-3.2(-8.0$ to -1.3$)$ & $P=0.512^{\mathrm{b}}$ \\
\hline ET PWVbeta [m/s] & $4.0(3.5-4.7)$ & $3.9(3.5-4.3)$ & $P=0.453^{\mathrm{b}}$ \\
\hline ET D max [mm] & $6.4 \pm 0.7$ & $5.9 \pm 0.7$ & $P=0.010^{\mathrm{a}}$ \\
\hline ET D min [mm] & $5.5 \pm 0.7$ & $5.1 \pm 0.7$ & $P=0.021^{\mathrm{a}}$ \\
\hline ET DATmax [ms] & $127.0(108-146)$ & $130.5(126-150)$ & $P=0.167^{\mathrm{b}}$ \\
\hline
\end{tabular}

$S B P$ systolic blood pressure, $D B P$ diastolic blood pressure, $A o S B P$ aortic (central) systolic blood pressure, AoDBP aortic (central) diastolic blood pressure, AoMAP aortic (central) mean blood pressure, SBPL systolic blood pressure load, $D B P L$ diastolic blood pressure load, $A I x 75 H R$ augmentation index normalized to heart rate of 75 beats per minute, $S E V R$ subendocardial viability ratio, $P W V$ pulse wave velocity, $c I M T$ common carotid artery intima-media thickness, ET ECHO-tracking, beta stiffness index, Ep pressure strain elasticity modulus, $A C$ arterial compliance, $A I x$ augmentation index, $D$ max maximal diameter of the artery, $D$ min minimal diameter of the artery, DATmax acceleration time to artery maximal diameter

${ }^{\mathrm{a}}$ Student $t$ test

${ }^{\mathrm{b}}$ Mann-Whitney $U$ test systolic blood pressure was found in $31(51.7 \%)$ and diastolic in $50(83.3 \%)$ children with $\mathrm{PH}$; elevated ABPM systolic blood pressure was revealed in $42(83.3 \%)$, diastolic in 9 (15.0\%), and MAP in $13(21.7 \%)$ patients with PH. Also, in the group of patients with $\mathrm{PH}$, abnormal PWV was found in 5 $(8.3 \%)$ and cIMT in $29(48.3 \%)$ patients.

Concentrations of circulating calcification inhibitors and parameters of calcium and phosphorus metabolism are presented in Table 3. $\mathrm{PH}$ patients were characterized by significantly lower FA level (340.57 \pm 70.43 vs. 389.19 $\pm 99.22[\mu \mathrm{g} / \mathrm{mL}], \mathrm{P}=0.019$ ) (Fig. 2) without differences in
OPG, sRANKL, and OPG/sRANKL and OPG/FA ratios. Calcium and phosphorus metabolism parameters remained within normal limits in all the studied children except for vitamin D concentrations. Vitamin D high supply $(25(\mathrm{OH}) \mathrm{D}>50-100 \mathrm{ng} / \mathrm{mL})$ was found in $1(1.7 \%)$ child with $\mathrm{PH}$, vitamin D optimal status $(25(\mathrm{OH}) \mathrm{D}>30-50 \mathrm{ng} /$ $\mathrm{mL})$ in $2(3.3 \%)$ patients with $\mathrm{PH}$ and in $2(10.0 \%)$ healthy children, vitamin D suboptimal status (25(OH)D 20-30 ng/ $\mathrm{mL})$ in $22(36.7 \%)$ patients with $\mathrm{PH}$ and in $8(40.0 \%)$ healthy individuals, vitamin $\mathrm{D}$ deficiency $(25(\mathrm{OH}) \mathrm{D}<$ $20->10 \mathrm{ng} / \mathrm{mL})$ in $32(53.3 \%)$ patients with $\mathrm{PH}$ and in 
Table 3 Markers of bone turnover and calcium-phosphorus metabolism parameters in children with primary hypertension and in healthy children

\begin{tabular}{|c|c|c|c|}
\hline Analyzed parameter & $\begin{array}{l}\text { Children with arterial } \\
\text { hypertension }(n=60)\end{array}$ & $\begin{array}{l}\text { Healthy children }(n= \\
\text { 20) }\end{array}$ & $P$ \\
\hline Fetuin $\mathrm{A}[\mu \mathrm{g} / \mathrm{mL}]$ & $340.57 \pm 70.43$ & $389.19 \pm 99.22$ & $P=0.019^{\mathrm{a}}$ \\
\hline $\mathrm{OPG}[\mathrm{pmol} / \mathrm{L}]$ & $3.89 \pm 0.86$ & $4.08 \pm 0.86$ & $P=0.412^{\mathrm{a}}$ \\
\hline sRANKL [pmol/L] & $113.41(89.74-173.25)$ & $139.00(92.17-224.11)$ & $P=0.474^{\mathrm{b}}$ \\
\hline $\begin{array}{c}\text { OPG/sRANKL } * 100 \\
{[\mathrm{pmol} / \mathrm{L}] /[\mathrm{pmol} / \mathrm{L}]}\end{array}$ & $3.43(1.94-4.83)$ & $2.58(2.00-4.31)$ & $P=0.621^{\mathrm{b}}$ \\
\hline $\begin{array}{r}\text { OPG/Fetuin A } * 100 \\
{[\mathrm{pmol} / \mathrm{L}] /[\mu \mathrm{g} / \mathrm{mL}]}\end{array}$ & $1.19 \pm 0.36$ & $1.11 \pm 0.34$ & $P=0.359^{\mathrm{a}}$ \\
\hline Calcium $[\mathrm{mg} / \mathrm{dL}]$ & $10.0 \pm 0.3$ & $9.8 \pm 0.3$ & $P=0.011^{\mathrm{a}}$ \\
\hline Phosphorus [mg/dL] & $4.4 \pm 0.7$ & $4.5 \pm 0.4$ & $P=0.383^{\mathrm{a}}$ \\
\hline $\begin{array}{l}\text { Calcium phosphorus product } \\
{\left[\mathrm{mg}^{2} / \mathrm{dL}^{2}\right]}\end{array}$ & $43.5 \pm 7.2$ & $43.9 \pm 3.9$ & $P=0.840^{\mathrm{a}}$ \\
\hline Parathormone $[\mathrm{pg} / \mathrm{mL}]$ & $24.3(16.9-35.5)$ & $19.7(14.9-31.2)$ & $P=0.230^{\mathrm{b}}$ \\
\hline Alkaline phosphatase [IU/L] & $107.0(80-153)$ & $152.0(93-197)$ & $P=0.115^{\mathrm{b}}$ \\
\hline $25(\mathrm{OH}) \mathrm{D}[\mathrm{ng} / \mathrm{mL}]$ & $19.3(15.6-22.7)$ & $20.6(15.8-25.9)$ & $P=0.527^{\mathrm{b}}$ \\
\hline
\end{tabular}

$O P G$ osteoprotegerin, $s R A N K L$ soluble ligand of the receptor activator of nuclear factor kappa-B

${ }^{\text {a }}$ Student $t$ test

${ }^{\mathrm{b}}$ Mann-Whitney $U$ test
$10(50.0 \%)$ healthy children; severe vitamin D deficiency $(25(\mathrm{OH}) \mathrm{D}<10 \mathrm{ng} / \mathrm{mL})$ was revealed in $3(5.0 \%)$ hypertensive children. Despite normocalcemia in all the studied children, serum calcium concentration was significantly higher in patients with $\mathrm{PH}$ compared to the control group $(10.0 \pm 0.3$ vs. $9.8 \pm 0.3[\mathrm{mg} / \mathrm{dL}], P=0.011)$.

In the group of 60 children with $\mathrm{PH}$, the levels of FA, OPG, sRANKL, and OPG/sRANKL and OPG/FA ratios did not differ significantly between boys and girls, and between those treated and not treated with antihypertensive medications.

The correlations of the analyzed biomarkers with clinical and biochemical parameters in children with $\mathrm{PH}$ are presented in Table 4. In hypertensive children, FA level correlated positively with serum calcium concentration $(R=0.389, P=$ $0.002)$, systolic blood pressure nighttime dipping $(R=$

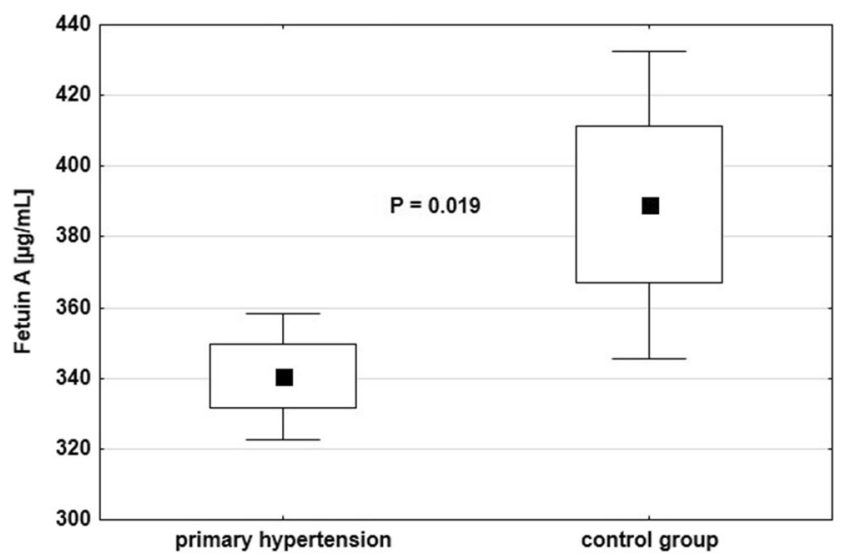

Fig. 2 Serum concentrations of fetuin A in children with primary hypertension and in control group
$0.266, P=0.040)$, and negatively with cIMT $(R=-0.279$, $P=0.031)$ (Fig. 3), ECHO-tracking augmentation index $(R=$ $-0.453, P<0.001)$, and DAT max $(R=-0.373, P=0.003)$. OPG level correlated positively with NLR $(R=0.264, P=$ $0.041)$ and PLR $(R=0.257, P=0.047)$, and negatively with ECHO-tracking $D \_\max (R=-0.263, P=0.043)$. sRANKL level correlated negatively with systolic blood pressure $(R=-$ $0.270, P=0.037)$, systolic and diastolic blood pressure loads in $\operatorname{ABPM}(R=-0.390, P=0.002$ and $R=-0.266, P=0.040$, respectively), and augmentation index $(R=-0.291, P=$ $0.024)$. OPG/sRANKL ratio correlated positively with systolic blood pressure load in ABPM $(R=0.350, P=0.006)$, and OPG/FA ratio with local arterial stiffness (ET) parameters: augmentation index $(R=0.297, P=0.021)$ and $D \_\max (R=$ $-0.268, P=0.039$ ). No additional correlations were found in treated and untreated patients.

In healthy children, positive correlations were observed between SRANKL, OPG/sRANKL ratio, and body measurement parameters (sRANKL vs. height Z-score: $R=0.540, P=$ 0.014; sRANKL vs. weight Z-score: $R=0.549, P=0.012$, sRANKL vs. BMI Z-score: $R=0.481, P=0.032$, OPG/ sRANKL vs. height Z-score: $R=-0.606, P=0.005$, OPG/ sRANKL vs. weight Z-score: $R=-0.477, P=0.034$ ), between OPG and total cholesterol and $(R=0.452, P=0.045)$ and between OPG/FA ratio and total and HDL-cholesterol ( $R$ $=0.546, P=0.013$ and $R=0.578, P=0.008$, respectively). In addition, OPG and SRANKL correlated positively with 25OHD level $(R=0.463, P=0.040$ and $R=0.540, P=$ 0.014 , respectively); FA and FA/OPG ratio correlated positively with PTH $(R=0.616, P=0.004$ and $R=-0.672, P=$ 0.001 , respectively). Correlations were observed also between FA, OPG/FA ratio, and AIx75HR $(R=-0.589, P=0.006, R$ 
Table 4 Correlations of biomarkers of bone metabolism with clinical and biochemical parameters in children with primary hypertension. Significant correlations $(P<0.05)$ are shown in bold

\begin{tabular}{|c|c|c|c|c|c|}
\hline & FA & OPG & sRANKL & $\begin{array}{l}\text { OPG/ } \\
\text { sRANKL }\end{array}$ & OPG/FA \\
\hline \multirow[t]{2}{*}{ NLR } & $R=0.005^{\mathrm{a}}$ & $R=0.264^{\mathrm{a}}$ & $R=-0.074^{\mathrm{a}}$ & $R=0.171^{\mathrm{a}}$ & $R=0.182^{\mathrm{a}}$ \\
\hline & $P=0.704$ & $P=\mathbf{0 . 0 4 1}$ & $P=0.572$ & $P=0.191$ & $P=0.164$ \\
\hline \multirow[t]{2}{*}{ PLR } & $R=-0.025^{\mathrm{b}}$ & $R=0.257^{\mathrm{b}}$ & $R=0.064^{\mathrm{a}}$ & $R=0.043^{\mathrm{a}}$ & $R=0.213^{\mathrm{b}}$ \\
\hline & $P=0.851$ & $P=\mathbf{0 . 0 4 7}$ & $P=0.626$ & $P=0.747$ & $P=0.102$ \\
\hline \multirow[t]{2}{*}{ Calcium $[\mathrm{mg} / \mathrm{dL}]$} & $\mathbf{R}=\mathbf{0 . 3 8 9 ^ { b }}$ & $R=0.051^{2}$ & $R=0.082^{\mathrm{a}}$ & $R=-0.054^{\mathrm{a}}$ & $R=-0.251^{\mathrm{b}}$ \\
\hline & $P=\mathbf{0 . 0 0 2}$ & $P=0.697$ & $P=0.533$ & $P=0.683$ & $P=0.053$ \\
\hline \multirow[t]{2}{*}{ ABPM SBP 24 h [mmHg] } & $R=-0.106^{\mathrm{b}}$ & $R=-0.007^{\mathrm{b}}$ & $R=-0.270^{\mathrm{a}}$ & $R=0.187^{\mathrm{a}}$ & $R=0.008^{\mathrm{b}}$ \\
\hline & $P=0.420$ & $P=0.960$ & $P=\mathbf{0 . 0 3 7}$ & $P=0.152$ & $P=0.951$ \\
\hline \multirow[t]{2}{*}{ ABPM SBPL 24 h [\%] } & $R=0.025^{\mathrm{a}}$ & $R=0.067^{\mathrm{a}}$ & $R=-0.390^{\mathrm{a}}$ & $R=0.350^{\mathrm{a}}$ & $R=0.090^{\mathrm{a}}$ \\
\hline & $P=0.850$ & $P=0.613$ & $P=\mathbf{0 . 0 0 2}$ & $P=\mathbf{0 . 0 0 6}$ & $P=0.492$ \\
\hline \multirow[t]{2}{*}{ ABPM DBPL 24 h [\%] } & $R=-0.001^{\mathrm{a}}$ & $R=-0.018^{\mathrm{a}}$ & $R=-0.266^{\mathrm{a}}$ & $R=0.200^{\mathrm{a}}$ & $R=0.012^{\mathrm{a}}$ \\
\hline & $P=0.993$ & $P=0.889$ & $P=\mathbf{0 . 0 4 0}$ & $P=0.126$ & $P=0.925$ \\
\hline \multirow[t]{2}{*}{ ABPM SBP DIP } & $R=0.266^{\mathrm{b}}$ & $R=0.016^{\mathrm{b}}$ & $R=-0.061^{\mathrm{a}}$ & $R=0.072^{\mathrm{a}}$ & $R=-0.152^{\mathrm{b}}$ \\
\hline & $P=\mathbf{0 . 0 4 0}$ & $P=0.901$ & $P=0.645$ & $P=0.584$ & $P=0.246$ \\
\hline \multirow[t]{2}{*}{ AIx75HR [\%] } & $R=0.087^{\mathrm{a}}$ & $R=-0.102^{\mathrm{a}}$ & $R=-0.291^{\mathrm{a}}$ & $R=0.208^{\mathrm{a}}$ & $R=-0.130^{\mathrm{a}}$ \\
\hline & $P=0.510$ & $P=0.437$ & $P=\mathbf{0 . 0 2 4}$ & $P=0.110$ & $P=0.322$ \\
\hline \multirow[t]{2}{*}{ cIMT [mm] } & $R=-0.279^{\mathrm{b}}$ & $R=0.007^{\mathrm{b}}$ & $R=-0.025^{\mathrm{a}}$ & $R=0.043^{\mathrm{a}}$ & $R=0.176^{\mathrm{b}}$ \\
\hline & $P=\mathbf{0 . 0 3 1}$ & $P=0.958$ & $P=0.851$ & $P=0.746$ & $P=0.179$ \\
\hline \multirow[t]{2}{*}{ cIMT Z-score } & $R=-0.281^{\mathrm{b}}$ & $R=0.039^{\mathrm{b}}$ & $R=-0.021^{\mathrm{a}}$ & $R=0.044^{\mathrm{a}}$ & $R=0.194^{\mathrm{b}}$ \\
\hline & $P=\mathbf{0 . 0 3 0}$ & $P=0.770$ & $P=0.874$ & $P=0.738$ & $P=0.137$ \\
\hline \multirow[t]{2}{*}{ ET AIx [\%] } & $R=-0.453^{\mathrm{a}}$ & $R=-0.069^{\mathrm{a}}$ & $R=-0.017^{\mathrm{a}}$ & $R=-0.009^{\mathrm{a}}$ & $\boldsymbol{R}=0.297^{\mathrm{a}}$ \\
\hline & $P<\mathbf{0 . 0 0 1}$ & $P=0.598$ & $P=0.895$ & $P=0.948$ & $P=\mathbf{0 . 0 2 1}$ \\
\hline \multirow[t]{2}{*}{ ET D_max [mm] } & $R=0.130^{\mathrm{b}}$ & $R=-0.263^{\mathrm{b}}$ & $R=-0.088^{\mathrm{a}}$ & $R=-0.008^{\mathrm{a}}$ & $R=-0.268^{\mathrm{b}}$ \\
\hline & $P=0.321$ & $P=\mathbf{0 . 0 4 3}$ & $P=0.501$ & $P=0.949$ & $P=\mathbf{0 . 0 3 9}$ \\
\hline \multirow[t]{2}{*}{ ET DAT max [ms] } & $R=-0.373^{\mathrm{a}}$ & $R=-0.114^{\mathrm{a}}$ & $R=0.146^{\mathrm{a}}$ & $R=-0.176^{\mathrm{a}}$ & $R=0.177^{\mathrm{a}}$ \\
\hline & $P=\mathbf{0 . 0 0 3}$ & $P=0.385$ & $P=0.266$ & $P=0.179$ & $P=0.177$ \\
\hline
\end{tabular}

$F A$ fetuin A, $O P G$ osteoprotegerin, $S R A N K L$ soluble ligand of the receptor activator of nuclear factor kappa-B, $N L R$ neutrophil-to-lymphocyte ratio, $P L R$ platelet-to-lymphocyte ratio, $A B P M$ ambulatory blood pressure monitoring, $S B P L$ systolic blood pressure load, $D B P L$ diastolic blood pressure load, AIx75HR augmentation index normalized to heart rate of 75 beats per minute, $c I M T$ common carotid artery intima-media thickness, ET ECHOtracking, $A I x$ augmentation index, $D$ max maximal diameter of the artery, DATmax acceleration time to artery maximal diameter

${ }^{a}$ Spearman's rank correlation

${ }^{\mathrm{b}}$ Pearson correlation
$=0.564, P=0.010$, respectively), and between $\mathrm{OPG} / \mathrm{FA}$, AoPP, and $\operatorname{SEVR}(R=-0.477, P=0.033, R=-0.465, P=$ $0.039)$. A table with correlations in the control group is included in the Supplementary Materials.

In multivariate analysis using forward step-wise regression, we found that in the entire group of 80 children, FA was a significant determinant for both cIMT [mm] and cIMT Zscore $\left(R^{2}=0.270\right.$ and $R^{2}=0.192$, respectively) (Table 5).

\section{Discussion}

Our single center cross-sectional analysis revealed that children with primary hypertension were characterized by lower fetuin A (FA) serum concentration, without differences in OPG, soluble ligand of the receptor activator of nuclear factor kappa-B (sRANKL), and OPG/FA and OPG/sRANKL ratios. We showed that low FA and sRANKL levels and high OPG/ FA and OPG/sRANKL ratios were related to elevated blood pressure and subclinical arterial damage in patients with primary hypertension. In addition, high $\mathrm{OPG} / \mathrm{FA}$ ratio may be associated with arterial stiffness also in healthy individuals.

A large proportion of hypertensive patients were characterized by the presence of subclinical arterial damage (early sign of hypertensive arteriosclerosis) —increased cIMT, despite a relatively short duration of hypertension (mean 1.5 years). We cannot exclude the possibility that in many of our patients the disease lasted longer but the diagnosis was delayed due to a 


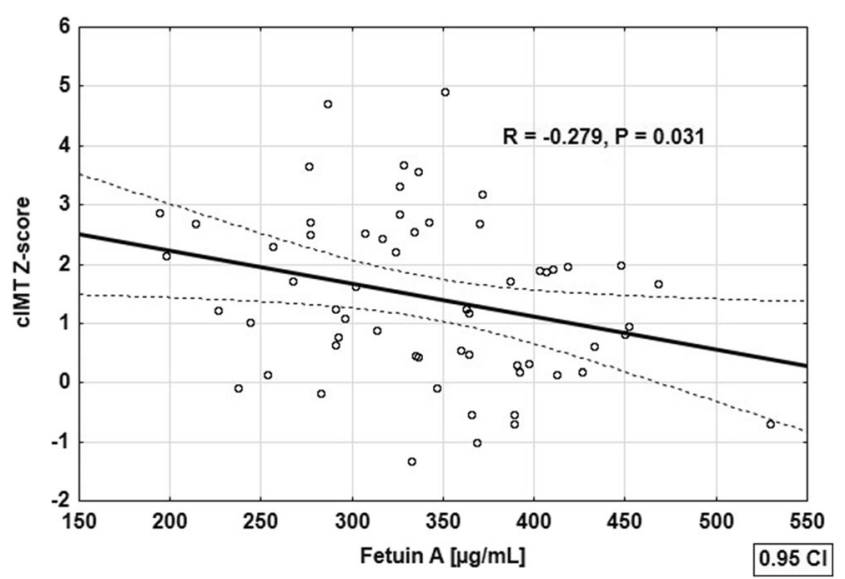

Fig. 3 Correlation between serum fetuin A concentration and common carotid artery intima media thickness in children with primary hypertension

silent clinical course or nonspecific symptoms. Similar to our results, other authors also found that subclinical arterial damage is not rare in this group of patients $[4,31]$. These findings highlight the fact that $\mathrm{PH}$ is by far not a benign phenomenon and carries a significant risk for cardiovascular sequelae in adult life. Our PWV results have been compared with normative values obtained from other devices also using the principle of applanation tonometry [27]. Of note, Stabouli et al. [32] and Kis et al. [33] found that the most frequently used techniques of measurement of aortic PWV provide comparable results and can be used interchangeably in the pediatric setting.

As high blood pressure influences various parts of the arterial tree to different extents, the assessment of local stiffness may provide additional information on target organ damage in hypertensive individuals. The assessment of carotid stiffness is of particular interest as stiffening of the carotid arteries increases pressure and flow pulsatility in the cerebral circulation and puts the patient at risk of a stroke and its sequelae. The assessment of carotid stiffness may be performed either by routine ultrasound examination in M-mode [28] or by high-

Table 5 Results of multivariate analysis by forward step-wise regression of determinants of markers of arterial damage in children with primary hypertension

\begin{tabular}{llll}
\hline & Beta & $95 \% \mathrm{CI}$ & $P$ \\
\hline cIMT $[\mathrm{mmHg}]$ & & & \\
$\quad$ Fetuin A $[\mu \mathrm{g} / \mathrm{mL}]$ & -0.208 & $(-0.407$ to -0.009$)$ & $P=0.041$ \\
$\quad$ SBP $[\mathrm{mmHg}]$ & 0.347 & $(0.146$ to 0.548$)$ & $P<0.001$ \\
cIMT Z-score & & & \\
$\quad$ Fetuin A $[\mu \mathrm{g} / \mathrm{mL}]$ & -0.224 & $(-0.435$ to -0.013$)$ & $P=0.038$ \\
SBP Z-score & 0.268 & $(0.054$ to 0.482$)$ & $P=0.015$ \\
\hline
\end{tabular}

$C I$ confidence interval, $c I M T$ common carotid artery intima-media thickness, $S B P$ systolic blood pressure resolution wall tracking systems analyzing the raw radiofrequency, e.g., E-tracking of Hitachi-Aloka [34]. Mean values of indices of local stiffness (beta, Ep, AIx, PWVbeta) were higher in children with $\mathrm{PH}$ but the difference did not reach statistical significance. Increased carotid stiffness had already been found in children with overweight and obesity (measured by E-tracking) [35] and with hypertension [4]. It is noteworthy that both these studies showed increased systolic and diastolic carotid artery dimensions in patients with cardiovascular risk factors, similar to our PH cohort [4, 35]. Carotid arterial diameter enlargement is a manifestation of arterial wall remodeling and is considered a risk factor for stroke, cardiovascular disease, and mortality [36].

Fetuin A, a member of the cystatin superfamily of cysteine protease inhibitors, is a negative acute-phase glycoprotein produced by the liver. It is a potent inhibitor of extraosseous calcification and is regarded as a marker for vascular inflammation $[6,10]$. Our hypertensive patients were characterized by significantly lower fetuin A serum concentrations compared to their healthy peers. Similarly, in patients with PH, FA level correlated negatively with cIMT and arterial stiffness evaluated by Etracking. In healthy controls, FA correlated negatively with AIx75HR but not with cIMT. Interestingly, in FA-knock-out mice, the aorta was unaltered, whereas the peripheral vessels in the skin and kidney were affected by extensive calcification [10]. Though the direct role of fetuin A in the process of arteriosclerosis is not known, it is hypothesized that FA Ca-P complex (calcyprotein) interacts with cell membrane proteins annexin II and VI - and inhibits transformation of vascular smooth vascular cells (VSMC) into osteoblast-like cells, and inhibits the function of bone morphogenetic protein $2[6,10$, $12]$. In addition, FA and type II TGF $\beta$-receptors have a sequence homology at the cytokine binding site. Thus, FA interacts with TGFbeta signaling and influences collagen and extracellular matrix production and arterial stiffness [37].

Numerous studies show that low fetuin A is related to increased risk of arterial damage and cardiovascular disease. Our results are consistent with the study by Guarneri et al. who also found lower FA level in adults with PH (mean age $46.9 \pm 11.8$ years) compared to their healthy peers, and showed negative correlation between FA and cIMT [15]. Negative correlations of fetuin A with cIMT [16] and arterial stiffness (evaluated as PWV and AIx75HR) [17, 18, 38] were also found in children with CKD. Finally, low plasma FA levels were associated with an increased risk of all-cause and CVD mortality in patients with coronary artery disease in a Chinese population [13]. Nevertheless, the final position of FA as a negative biomarker of cardiovascular burden is not yet confirmed, as numerous studies have shown no significant relationship between FA and cardiovascular injury markers in various groups of high-risk pediatric patients, e.g., in obese adolescents [19] or in children after kidney transplantation [20]. 
In our group, fetuin A level was positively correlated with serum calcium, but only in hypertensive patients. Similar dependence was revealed by Makulska et al. in children with CKD [17]. It is possible that in patients with increased cardiovascular risk, the level of FA increases alongside calcium concentration as a preventive measure against soft tissue calcification. FA level negatively correlates with subclinical inflammation markers and is considered a negative inflammatory reactant. In adult patients with PH, FA level correlated negatively with inflammatory cytokines: tumor necrosis factor alpha and interleukin 6 [15]. PH is nowadays considered as a state of subclinical inflammation [1]. In line with this hypothesis, our hypertensive patients were characterized by a higher level of CBC-derived markers of subclinical inflammation NLR - as compared to their healthy peers. The downregulation of FA in inflammatory states, such as in the course of $\mathrm{PH}$, might be the mechanism facilitating early vascular damage in these individuals.

In vitro and animal studies suggest that OPG acts as a calcification inhibitor; however, the direct mechanism underlying its inhibitory action is not yet described. The vessel wall is a site of abundant OPG production, and in line with this OPG knock-out mice exhibit aorta and renal artery calcification [11]. In our cohort of hypertensive patients, OPG level was not directly related to blood pressure or arterial damage, but sRANKL level showed a negative relationship with blood pressure and arterial stiffness.

The vascular role of OPG is probably multifaceted and includes interaction with its ligands, with $\mathrm{TNF} \alpha$, and with NF-kappaB pathway. In addition, OPG inhibits alkaline phosphatase-mediated osteogenic differentiation of vascular cells $[8,9]$. However, clinical studies suggest that serum OPG increases along with the extent of vascular calcification. It is hypothesized that excessive vascular lesions induce further production of OPG to compensate for the process of vascular calcification. OPG level was significantly elevated in adults with $\mathrm{PH}$ and increased arterial stiffness [14, 39], and is considered an independent risk factor of cardiovascular risk in adults [40]. However, data on circulating sRANKL concentrations are sparse and contradictory. A positive relationship between SRANKL and the risk of cardiovascular events was revealed, but not with cIMT, suggesting different pathway to vascular damage [41]. The authors of the aforementioned study hypothesized that either sRANKL was related to unstable plaques and not to arteriosclerotic burden in general, or the increased SRANKL level was a consequence of plaque inflammation [36, 41]. Similarly, Shroff et al. found a positive correlation between OPG and PWV without any correlation between OPG/sRANKL, sRANKL, and arterial damage parameters in children with CKD [38]. Also, Greek authors found no relationship between OPG, sRANKL, and cIMT in children and adolescents with type 1 diabetes mellitus [42]. Contrary to those studies, our results suggest that high
sRANKL levels could exert a protective role against blood pressure elevation and arterial stiffness in hypertensive patients. Further, prospective studies are needed to confirm this in other groups of patients and to unmask the underlying mechanism.

Of note, in patients with $\mathrm{PH}$, we have demonstrated a positive correlation between OPG and $\mathrm{CBC}$-derived markers of subclinical inflammation - NLR and PLR. OPG is steadily released from vascular endothelial cells in response to inflammatory stimuli, suggesting that it plays a modulatory role in vascular injury, inflammation, and atherosclerosis [43]. OPG level positively correlates with CRP in adult patients with metabolic syndrome [44], and TNF $\alpha$ together with IL-1 $\beta$ stimulated production of OPG by human retinal microvascular endothelial cells [45]. Our results suggest that subclinical inflammation might be the link between OPG/RANK/sRANKL axis, elevation of blood pressure, and target organ damage in pediatric patients with $\mathrm{PH}$.

The particular strength of our study lies in the extensive evaluation of blood pressure and numerous markers of arterial damage evaluated by different techniques, as well as detailed biochemical evaluation performed in both hypertensive and normotensive children. These detailed characteristics allow us to get better insight into the role of three molecules, namely FA, OPG, and sRANKL, associated with vascular calcification. The main limitations are the small number of analyzed children (especially in the control group, i.e., 20 children) and the cross-sectional design of the study, which prevents obtaining solid conclusions on causal relationships between FA, OPG, sRANKL levels, and the analyzed parameters. Additionally, subclinical inflammation was evaluated only on the basis of CBC-derived parameters with indefinite clinical significance, and we have not evaluated more precise markers like high-sensitivity C-reactive protein (hsCRP). Also, some literature data suggest that calcification inhibitors might be related to body composition - we found only a positive correlation between sRANKL and BMI Z-score in healthy children, but we have not performed deeper anthropological analysis (e.g., waist and hip measurements). Despite these limitations, our findings can be informative for larger population studies of cardiovascular disease in young patients with PH. Further prospective and interventional studies are needed to evaluate possible preventive measures against calcification-mediated early arterial damage in these patients.

\section{Conclusions}

This study shows for the first time that in children with $\mathrm{PH}$ arterial damage is related to lower fetuin A concentrations.

Supplementary Information The online version contains supplementary material available at https://doi.org/10.1007/s00467-021-04957-5. 
Authors' contributions Piotr Skrzypczyk - study conception and design, data collection, statistical analysis, data interpretation, manuscript preparation, literature search. Anna Stelmaszczyk-Emmel — data collection, data interpretation, manuscript preparation. Michał Szyszka - data collection, data interpretation, manuscript preparation. Anna Ofiara data collection, data interpretation, manuscript preparation. Małgorzata Pańczyk-Tomaszewska - study conception and design, data interpretation, manuscript preparation, literature search, critical revision of the manuscript, supervisor of the study. The first draft of the manuscript was written by Piotr Skrzypczyk and all authors commented on previous versions of the manuscript. All authors read and approved the final manuscript.

Funding The study was funded from statutory funds of the Department of Pediatrics and Nephrology, Medical University of Warsaw.

Availability of data and material All data generated or analyzed during this study are included in this published article and its supplementary information files.

\section{Declarations}

Ethical approval The research project was approved by Institutional Review Board (approval No. KB/58/2016). All procedures were performed in accordance with the ethical standards of our institution and the 1964 Declaration of Helsinki and its later amendments on the treatment of human subjects.

Consent to participate Informed consent was obtained from all participants ( $\geq 16$ years) and their representatives.

Conflict of interest The authors declare no conflict of interest.

Open Access This article is licensed under a Creative Commons Attribution 4.0 International License, which permits use, sharing, adaptation, distribution and reproduction in any medium or format, as long as you give appropriate credit to the original author(s) and the source, provide a link to the Creative Commons licence, and indicate if changes were made. The images or other third party material in this article are included in the article's Creative Commons licence, unless indicated otherwise in a credit line to the material. If material is not included in the article's Creative Commons licence and your intended use is not permitted by statutory regulation or exceeds the permitted use, you will need to obtain permission directly from the copyright holder. To view a copy of this licence, visit http://creativecommons.org/licenses/by/4.0/.

\section{References}

1. Litwin M, Feber J, Niemirska A, Michałkiewicz J (2016) Primary hypertension is a disease of premature vascular aging associated with neuro-immuno-metabolic abnormalities. Pediatr Nephrol 3: 185-194. https://doi.org/10.1007/s00467-015-3065-y

2. Vlachopoulos C, Aznaouridis K, Stefanadis C (2010) Prediction of cardiovascular events and all-cause mortality with arterial stiffness: a systematic review and meta-analysis. J Am Coll Cardiol 55:13181327. https://doi.org/10.1016/j.jacc.2009.10.061

3. Lorenz MW, Markus HS, Bots ML, Rosvall M, Sitzer M (2007) Prediction of clinical cardiovascular events with carotid intima-media thickness: a systematic review and meta-analysis. Circulation 115:459 467. https://doi.org/10.1161/CIRCULATIONAHA.106.628875
4. Litwin M, Trelewicz J, Wawer Z, Antoniewicz J, Wierzbicka A, Rajszys P, Grenda R (2004) Intima-media thickness and arterial elasticity in hypertensive children: controlled study. Pediatr Nephrol 19:767-774. https://doi.org/10.1007/s00467-004-1480-6

5. Durham AL, Speer MY, Scatena M, Giachelli CM, Shanahan CM (2018) Role of smooth muscle cells in vascular calcification: implications in atherosclerosis and arterial stiffness. Cardiovasc Res 114: 590-600. https://doi.org/10.1093/cvr/cvy010

6. Schaefer C, Heiss A, Schwarz A, Westenfeld R, Ketteler M, Floege J, Muller-Esterl W, Schinke T, Jahnen-Dechent W (2003) The serum protein alpha 2-Heremans-Schmid glycoprotein/fetuin-A is a systemically acting inhibitor of ectopic calcification. J Clin Invest 112:357-366. https://doi.org/10.1172/JCI17202

7. Price PA, Thomas GR, Bardini AW, Figueira WF, Caputo JM, Williamson MK (2002) Discovery of a high molecular weight complex of calcium, phosphate, fetuin and matrix gammacarboxyglutamic acid protein in the serum of etidronate-treated rats. J Biol Chem 277:3926-3934. https://doi.org/10.1074/jbc. M106366200

8. Van Campenhout A, Golledge J (2009) Osteoprotegerin vascular calcification and atherosclerosis. Atherosclerosis 204:321-329. https://doi.org/10.1016/j.atherosclerosis.2008.09.033

9. Liu W, Zhang X (2015) Receptor activator of nuclear factor-kB ligand (RANKL)/RANK/osteoprotegerin system in bone and other tissues (review). Mol Med Rep 11:3212-3218. https://doi.org/10. 3892/mmr.2015.3152

10. Merx MW, Schäfer C, Westenfeld R, Brandenburg V, Hidajat S, Weber C, Ketteler M, Jahnen-Dechent W (2005) Myocardial stiffness, cardiac remodeling, and diastolic dysfunction in calcificationprone fetuin-A-deficient mice. J Am Soc Nephrol 16:3357-3364. https://doi.org/10.1681/ASN.2005040365

11. Bucay N, Sarosi I, Dunstan CR, Morony S, Terpley J, Capparelli C, Scully S, Tan HL, Xu W, Lacey DL, Boyle WJ, Simonet WS (1998) Osteoprotegerin-deficient mice develop early onset osteoporosis and arterial calcification. Genes Dev 12:1260-1268. https:// doi.org/10.1101/gad.12.9.1260

12. Coen G, Manni M, Agnoli A, Balducci A, Dessi M, De Angelis S, Jankovic L, Mantella D, Morosetti M, Naticchia A, Nofroni I, Romagnoli A, Gallucci MT, Tomassini M, Simonetti G, Splendiani G (2006) Cardiac calcifications: fetuin-A and other risk factors in hemodialysis patients. ASAIO J 52:150-156. https://doi. org/10.1097/01.mat.0000202606.44826.6b

13. Chen X, Zhang Y, Chen Q, Li Q, Li Y, Ling W (2017) Lower plasma fetuin-A levels are associated with a higher mortality risk in patients with coronary artery disease. Arterioscler Thromb Vasc Biol 37:2213-2219. https://doi.org/10.1161/ATVBAHA.117. 309700

14. Lee CJ, Wang JH, Chen ML, Yang CF, Chen YC, Hsu BG (2015) Serum osteoprotegerin is associated with arterial stiffness assessed according to the cardio-ankle vascular index in hypertensive patients. J Atheroscler Thromb 22:304-312. https://doi.org/10.5551/ jat. 25882

15. Guarneri M, Geraci C, Incalcaterra F, Arsena F, Mulè G, Vaccaro F, Luna C, Cerasola G, Cottone S (2013) Subclinical atherosclerosis and fetuin-A plasma levels in essential hypertensive patients. Hypertens Res 36:129-133. https://doi.org/10.1038/hr.2012.136

16. Ziółkowska H, Brzewski M, Roszkowska-Blaim M (2008) Determinants of the intima media thickness in children and adolescents with chronic kidney disease. Pediatr Nephrol 23:805-811. https://doi.org/10.1007/s00467-007-0733-6

17. Makulska I, Szczepańska M, Drożdż D, Polak-Jonkisz D, Zwolińska D (2019) The importance of fetuin-A in vascular calcification in children with chronic kidney disease. Adv Clin Exp Med 28:499-505. https://doi.org/10.17219/acem/82517

18. Kis E, Cseprekál O, Bíró E, Kelen K, Ferenczi D, Kerti A, Szabó AJ, Szabó A, Reusz GS (2009) Effects of bone and mineral 
metabolism on arterial elasticity in chronic renal failure. Pediatr Nephrol 24:2413-2420. https://doi.org/10.1007/s00467-009-12929

19. Manco M, Nobili V, Alisi A, Panera N, Handberg A (2017) Arterial stiffness, thickness and association to suitable novel markers of risk at the origin of cardiovascular disease in obese children. Int J Med Sci 14:711-720. https://doi.org/10.7150/ijms.20126

20. van Summeren MJH, Hameleers JM, Schurgers LJ, Hoeks AP, Uiterwaal CS, Krüger T, Vermeer C, Kuis W, Lilien MR (2008) Circulating calcification inhibitors and vascular properties in children after renal transplantation. Pediatr Nephrol 23:985-993. https://doi.org/10.1007/s00467-007-0743-4

21. Lurbe E, Agabiti-Rosei E, Cruickshank JK, Dominiczak A, Erdine S, Hirth A, Invitti C, Litwin M, Mancia G, Pall D, Rascher W, Redon J, Schaefer F, Seeman T, Sinha M, Stabouli S, Webb NJ, Wühl E, Zanchetti A (2016) 2016 European Society of Hypertension guidelines for the management of high blood pressure in children and adolescents. J Hypertens 34:1887-1920. https://doi. org/10.1097/HJH.0000000000001039

22. Rusińska A, Płudowski P, Walczak M, Borszewska-Kornacka MK, Bossowski A, Chlebna-Sokół D, Czech-Kowalska J, Dobrzańska A, Franek E, Helwich E, Jackowska T, Kalina MA, Konstantynowicz J, Książyk J, Lewiński A, Łukaszkiewicz J, Marcinowska-Suchowierska E, Mazur A, Michałus I, PeregudPogorzelski J, Romanowska H, Ruchała M, Socha P, Szalecki M, Wielgoś M, Zwolińska D, Zygmunt A (2018) Vitamin D supplementation guidelines for general population and groups at risk of vitamin D deficiency in Poland-recommendations of the Polish Society of Pediatric Endocrinology and Diabetes and the expert panel with participation of national specialist consultants and representatives of scientific societies - 2018 update. Front Endocrinol (Lausanne) 9:246. https://doi.org/10.3389/fendo.2018.00246

23. Skrzypczyk P, Przychodzień J, Mizerska-Wasiak M, KuźmaMroczkowska E, Okarska-Napierała M, Górska E, StelmaszczykEmmel A, Demkow U, Pańczyk-Tomaszewska M (2017) Renalase in children with glomerular kidney diseases. Adv Exp Med Biol 1021:81-92. https://doi.org/10.1007/5584 2017 22

24. Skrzypczyk P, Ozimek A, Ofiara A, Szyszka M, Sołtyski J, Stelmaszczyk-Emmel A, Górska E, Pańczyk-Tomaszewska M (2019) Markers of endothelial injury and subclinical inflammation in children and adolescents with primary hypertension. Centr Eur J Immunol 4:253-261. https://doi.org/10.5114/ceji.2019.89597

25. Kułaga Z, Litwin M, Grajda A, Kułaga K, Gurzkowska B, Góźdż M, Pan H, OLAF Study Group (2012) Oscillometric blood pressure percentiles for Polish normal-weight school-aged children and adolescents. J Hypertens 30:1942-1954. https://doi.org/10.1097/HJH. 0b013e328356abad

26. Flynn JT, Daniels SR, Hayman LL, Maahs DM, BW MC, Mitsnefes M, Zachariah JP, Urbina EM, American Heart Association Atherosclerosis, Hypertension and Obesity in Youth Committee of the Council on Cardiovascular Disease in the Young (2014) Update: ambulatory blood pressure monitoring in children and adolescents: a scientific statement from the American Heart Association. Hypertension 63:1116-1135. https://doi.org/10. 1161/HYP.0000000000000007

27. Reusz GS, Cseprekal O, Temmar M, Kis E, Cherif AB, Thaleb A, Fekete A, Szabó AJ, Benetos A, Salvi P (2010) Reference values of pulse wave velocity in healthy children and teenagers. Hypertension 56:217-224. https://doi.org/10.1161/ HYPERTENSIONAHA.110.152686

28. Doyon A, Kracht D, Bayazit AK, Deveci M, Duzova A, Krmar RT, Litwin M, Niemirska A, Oguz B, Schmidt BM, Sözeri B, Querfeld U, Melk A, Schaefer F, Wühl E, 4C Study Consortium (2013) Carotid artery intima-media thickness and distensibility in children and adolescents: reference values and role of body dimensions.
Hypertension 62:550-556. https://doi.org/10.1161/ HYPERTENSIONAHA.113.01297

29. Kułaga Z, Litwin M, Tkaczyk M, Palczewska I, Zajączkowska M, Zwolińska D, Krynicki T, Wasilewska A, Moczulska A, MorawiecKnysak A, Barwicka K, Grajda A, Gurzkowska B, Napieralska E, Pan H (2011) Polish 2010 growth references for school-aged children and adolescents. Eur J Pediatr 170:599-609. https://doi.org/ 10.1007/s00431-010-1329-x

30. Schwartz GJ, Muñoz A, Schneider MF, Mak RH, Kaskel F, Warady BA, Furth SL (2009) New equations to estimate GFR in children with CKD. J Am Soc Nephrol 20:629-637. https://doi.org/ 10.1681/ASN.2008030287

31. Stabouli S, Papakatsika S, Kotronis G, Papadopoulou-Legbelou K, Rizos Z, Kotsis V (2015) Arterial stiffness and SBP variability in children and adolescents. J Hypertens 33:88-95. https://doi.org/10. 1097/HJH.0000000000000369

32. Stabouli S, Printza N, Zervas C, Dotis J, Chrysaidou K, Maliahova O, Antza C, Papachristou F, Kotsis V (2019) Comparison of the SphygmoCor XCEL device with applanation tonometry for pulse wave velocity and central blood pressure assessment in youth. J Hypertens 37:30-36. https://doi.org/10.1097/hjh. 0000000000001819

33. Kis E, Cseprekál O, Kerti A, Salvi P, Benetos A, Tisler A, Szabó A, Tulassay T, Reusz GS (2011) Measurement of pulse wave velocity in children and young adults: a comparative study using three different devices. Hypertens Res 34:1197-1202. https://doi.org/10. 1038/hr.2011.103

34. Uejima T, Dunstan FD, Arbustini E, Łoboz-Grudzień K, Hughes AD, Carerj S, Favalli V, Antonini-Canterin F, Vriz O, Vinereanu D, Zamorano JL, Popescu BA, Evangelista A, Lancellotti P, Lefthériotis G, Kozakova M, Palombo C, Fraser AG, E-Tracking International Collaboration Group (ETIC) (2020) Age-specific reference values for carotid arterial stiffness estimated by ultrasonic wall tracking. J Hum Hypertens 34:214-222. https://doi.org/10. 1038/s41371-019-0228-5

35. Pandit D, Kinare A, Chiplonkar S, Khadilkar A, Khadilkar V (2011) Carotid arterial stiffness in overweight and obese Indian children. J Pediatr Endocrinol Metab 24:97-102. https://doi.org/ 10.1515/jpem.2011.086

36. Sedaghat S, van Sloten TT, Laurent S, London GM, Pannier B, Kavousi M, Mattace-Raso F, Franco OH, Boutouyrie P, Ikram MA, Stehouwer CDA (2018) Common carotid artery diameter and risk of cardiovascular events and mortality: pooled analyses of four cohort studies. Hypertension 72:85-92. https://doi.org/10. 1161/HYPERTENSIONAHA.118.11253

37. Demetriou M, Binkert C, Sukhu B, Tenenbaum H, Dennis J (1996) Fetuin/alpha2-HS glycoprotein is a transforming growth factor-beta type II receptor mimic and cytokine antagonist. J Biol Chem 271: 12755-12761. https://doi.org/10.1074/jbc.271.22.12755

38. Shroff RC, Shah V, Hiorns MP, Schoppet M, Hofbauer LC, Hawa G, Schurgers LJ, Singhal A, Merryweather I, Brogan P, Shanahan C, Deanfield J, Rees L (2008) The circulating calcification inhibitors, fetuin-A and osteoprotegerin, but not Matrix Gla protein, are associated with vascular stiffness and calcification in children on dialysis. Nephrol Dial Transplant 23:3263-3271. https://doi.org/10. 1093/ndt/gfn226

39. Wang JH, Lee CJ, Chen ML, Yang CF, Chen YC, Hsu BG (2014) Association of serum osteoprotegerin levels with carotid-femoral pulse wave velocity in hypertensive patients. J Clin Hypertens (Greenwich) 16:301-308. https://doi.org/10.1111/jch.12288

40. Tschiderer L, Willeit J, Schett G, Kiechl S, Willeit P (2017) Osteoprotegerin concentration and risk of cardiovascular outcomes in general population studies: Literature-based meta-analysis involving 26,442 participants. PLoS One 12:e0183910. https://doi. org/10.1371/journal.pone.0183910 
41. Kiechl S, Schett G, Schwaiger J, Seppi K, Eder P, Egger G, Santer P, Mayr A, Xu Q, Willeit J (2007) Soluble receptor activator of nuclear factor- B ligand and risk for cardiovascular disease. Circulation 116:385-391. https://doi.org/10.1161/ CIRCULATIONAHA.106.686774

42. Lambrinoudaki I, Tsouvalas E, Vakaki M, Kaparos G, Stamatelopoulos K, Augoulea A, Pliatsika P, Alexandrou A, Creatsa M, Karavanaki K (2013) Osteoprotegerin, soluble receptor activator of nuclear factor- $\mathrm{B}$ ligand, and subclinical atherosclerosis in children and adolescents with type 1 diabetes mellitus. Int $\mathrm{J}$ Endocrinol 2013:102120. https://doi.org/10.1155/2013/102120

43. Rochette L, Meloux A, Rigal E, Zeller M, Cottin Y, Vergely C (2018) The role of osteoprotegerin in the crosstalk between vessels and bone: Its potential utility as a marker of cardiometabolic diseases. Pharmacol Ther 182:115-132. https://doi.org/10.1016/j. pharmthera.2017.08.015
44. Musialik K, Szulińska M, Hen K, Skrypnik D, Bogdański P (2017) The relation between osteoprotegerin, inflammatory processes, and atherosclerosis in patients with metabolic syndrome. Eur Rev Med Pharmacol Sci 21:4379-4385

45. Abu El-Asrar AM, Struyf S, Mohammad G, Gouwy M, Rytinx P, Siddiquei MM, Hernández C, Alam K, Mousa A, De Hertogh G, Opdenakker G, Simó R (2017) Osteoprotegerin is a new regulator of inflammation and angiogenesis in proliferative diabetic retinopathy. Invest Ophthalmol Vis Sci 58:3189-3201. https://doi.org/10. 1167/iovs.16-20993

Publisher's note Springer Nature remains neutral with regard to jurisdictional claims in published maps and institutional affiliations. 